\title{
Designing for Diversity and Designing for Disability: New Opportunities for Libraries to Expand Their Support and Advocacy for People with Disabilities
}

Paul T. Jaeger, University of Maryland

\begin{abstract}
Libraries have a long history of support for and commitment to disabled people, far longer than most other public institutions in society. In some communities in North America, dedicated library services for disabled people have been provided without interruption for over a hundred years. As the social and political climate becomes, once again, increasingly difficult for and hostile to disabled people, libraries have the opportunity to bring more focus to disability in the design of their own programs and to expand their roles as advocates and allies of disabled people beyond the walls of the library. This article is written in the context of the U.S. and focuses primarily on the current U.S. situation, though a few international examples are also used to illustrate key points. While the U.S. is the primary focus, the implications and relevance of many discussed issues will resonate with the global community and echo the concerns of disabled individuals and library and information science professionals in other countries.
\end{abstract}

Keywords: advocacy; disability; library services; politics; policy

Publication Type: research article

\section{Welcome to Crippled America}

$\mathrm{T}$ he 2016 presidential election in the U.S. was unnerving for many diverse and disadvantaged populations, and disabled people were not left out. Throughout the course of the campaign, disabled people were either simply ignored or tokenized in online forums, like Facebook groups, with one notable exception (Cork, Jaeger, Jette, \& Ebrahimoff, 2016). The exception, of course, won the election after being repeatedly recorded mocking disabled people, subsequently denying that he mocked disabled people in spite of the recordings, blaming disabled people for violence (Cork et al., 2016), and also issuing a campaign book entitled Crippled America (Trump, 2015), an obvious slur against disabled people. While we could have experienced campaign rhetoric celebrating the 25th anniversary of the passage of the Americans with Disabilities Act (ADA; 42 U.S.C.A. 12101 et seq.) in 2015 and demanding more progress for the roughly $20 \%$ of the U.S. population who identify as disabled (Brault, 2012), disabled people instead were treated to being ignored, infantilized, ridiculed, or demonized.

The new presidential administration has reinforced this perception of working to deny the civil rights of disabled people by appointing a Secretary of Education who has publicly asserted that she believes that states should not be required to provide a public education to disabled students; appointing a Supreme Court justice who has ruled that disability rights laws should be enforced as minimally as possible; and proposing a budget that slashed funding for many social services and institutions that are central to the lives of many disabled people, from Medicaid to health research and from food assistance to public libraries (Achenbach \& Sun, 2017; Davidson, 2017; 
Douglass, Gorham, Hill, Hoffman, Jaeger, Jindal, \& St. Jean, 2017; Jaeger, Gorham, Taylor, Sarin, \& Kettnich, 2017; Snell, Paletta, \& DeBonis, 2017; Strauss, 2017a, 2017b, 2017c). The administration has even gone to great lengths to remove information that provides guidance about the rights of disabled people from government websites (Balingit, 2017).

The standby fantasy of moving to Canada, entertained by those offended by the new presidential administration, is out of reach for many disabled people in the U.S., as Canada uses eugenicsbased immigration standards that are designed to keep out disabled people, even those who already have a job lined up when trying to immigrate (Zaikowski, 2017). Even if disability were not a barrier to entry, such immigration would not seem to be much of an improvement for disabled people in the U.S., at least based on the description of disabled Canadians as "absent citizens" in their own country due to systematic oppression through policy and politics in Canada (Prince, 2009). As glum as the situation may seem for disabled people in the U.S., it is really a much more global problem.

\section{Welcome to Wherever You Are}

In brief, the history of disability encompasses socially accepted infanticide of children born with disabilities; persistent and extreme desexualizing of disabled people; limitation of employment opportunities at various times to beggar, circus freak, clown, slave, or prostitute; the eugenics movement; forced institutionalization; being left starving and unhoused; being classified as not human or without a soul; not being counted in census data; being hidden or killed; and so much other vile treatment around the world and throughout recorded history (for overviews of this history, see Albrecht, Seelman, \& Bury, 2001; Hirschmann, \& Linker, 2015; Jaeger \& Bowman, 2005; Longmore \& Umansky, 2000; Reilly, 1991; Stiker, 1999).

It is worth remembering that in times of heightened nationalism, disabled people are particularly vulnerable as a group and can quickly become the quintessence of otherness. In Nazi Germany, for example, disabled people were the first group targeted for elimination because the government determined that their elimination was actually widely supported by the public. The German government did public opinion polling and found that there was little resistance to the extermination of people with disabilities-only $20 \%$ said "no, under any circumstances" (Andre, 2003, n.p.). The subsequent German Law on Euthanasia for the Incurably Ill authorized the extermination of people who "desire an end to their suffering due to incurable illness, or who are incapable of productive existence as a result of incurable chronic ailment" and referred to people with disabilities as having a "worthless life" or being "unworthy of life" (Andre, 2003, n.p.). The sterilization and euthanasia program was called "T4," and it led to the sterilization of more than 400,000 and extermination of more than 300,000 Europeans with disabilities in the 1930s (Knittel, 2015). The organs of those who had been euthanized were often harvested by scientists for research purposes (Friedlander, 1995). While there is no reason to expect a return to those levels of horror, the extreme possibilities are always useful to keep in mind.

News stories from other countries in recent years have also served to highlight the unique isolation of disabled persons in the current national and global political climates. When a man in Japan publicly informed government employees that he planned to kill disabled people, no one did anything stop him, and he eventually killed several dozen disabled people (Willingham, 2016). Aside from the abject horror of the crime and the apathy shown toward disabled people in Japan, the world's reaction-or a lack thereof-was just as resounding. For example, Twitter users, who notoriously create a hashtag and campaign around almost everything, could not even muster a hashtag for a mass slaughter of disabled people in Japan. The lack of response on Twitter demonstrates the ignorance about and the absence of empathy for disability, which caused one author to label the worldwide situation as “disability erasure" (Willingham, 2016, n.p.).

The International Journal of Information, Diversity, \& Inclusion, 2(1-2), 2018

ISSN 2574-3430, publish.lib.umd.edu/IJIDI/ 


\section{Erasure in Percentages}

The recent census numbers from the U.S. Census Bureau suggest that 54.4 million Americans have a disability, which is $18.7 \%$ of the overall population, making it the largest minority group in the U.S. In part due to an aging population, the number of individuals with some type of disability is anticipated to grow even further (Brault, 2012). In many other nations, disabled people are also a major-if not the largest-minority population; the total number of disabled people worldwide is estimated to be one billion people, or $15 \%$ of the world's population (World Bank, 2017).

Disabled people are hardly alone in feeling discomfort and anxiety in the current political climate in the U.S. However, even with the exceptional levels of exclusion that disabled people faced before American society embraced the politics of fear and hatred, the current environment is uniquely hostile to disabled people. In the U.S., disabled people "win" most of the statistics that no group wants to win. For many years, disabled people have been the population with the highest percentage living in poverty, the highest percentage unemployed, the lowest percentage graduating from high school, the lowest percentage graduating from college, and the lowest percentage with home Internet access, among many other depressing figures (for a detailed overview of these data, see Cork et al., 2016; Jaeger, 2013, 2015).

The casual dehumanization of disabled people is hardly new; there are many disabled people alive today who were forcibly sterilized by the state, a practice that continued into the $1970 \mathrm{~s}$ in the U.S. and other nations, and in some nations into this millennium (Bulmer, 2003; Gillham, 2001; Pfieffer, 1999). Even when disabled people have achieved a recognition of their rights, the end result is not necessarily equitable; an example is the separate but unequal education afforded to many disabled public school students who are placed in "special" education (Jaeger \& Bowman, 2002, 2005). Now, however, this dehumanization is coupled with a public campaign and a presidency that seem to have left resentment and hatred tattooed onto the air that we breathe.

\section{Making Diversity More Inclusive}

A key step in the inclusion of disabled people is greater recognition that the concept of disability-as well as the accompanying disadvantages and exclusions-is very much a creation of society. In much of the past and present discourse, disability has been seen through the lens of the so-called medical, or individual, model, whereby it is defined as an individual characteristic or, rather, an individual deficiency or impediment. This model, however, "typically ignore[s] the impact of social and physical environments, even though these factors have the potential to facilitate or preclude functioning in a given role" (Shigaki, Anderson, Howald, Henson, \& Gregg, 2012, p. 560, citing Smart, 2001). Under this way of thinking, disabled people have deficiencies that they must compensate for and adapt to societal expectations (Stroman, 2003). The medical model still reflects the way that disability is viewed in the majority of nations (Prince, 2009).

Rather than focusing on individual differences as the root of disability, social models of disability take environmental influences into account (e.g., Shigaki et al., 2012), and, viewed through their lens, disability is created by societies. That is to say, "[t]o a large extent, disability is a social construct" (Schmetzke, 2002, p. 135). The move to a social model perspective has proven an instrumental tool in advocacy for disabled people, as it has helped to translate disability issues and experiences into broader contexts of civil rights and human rights (Bagenstos, 2009; Crouser, 2009; Johnson, 2006).

Disability reflects the "natural physical, social, and cultural variability" of living things (Scotch 
\& Schriner, 1997, p. 154) and has been present in every human culture through time (Scheer \& Gross, 1998). There is no reason that certain differences are deemed disabilities and others are not, except for the fact that society has defined them as such. Some differences, like the ability to throw an oblong ball a long distance while not being knocked over by large people trying to tackle you, are deemed worthy of adulation and heaps of cash. Others are deemed unusual but not really worth paying much attention to in most contexts, like hair color or freckles.

Yet, certain differences become disabilities-physical or cognitive differences that are treated as social stigmas and detriments (Jaeger \& Bowman, 2002). Decisions about what is normal and what is not then serve to classify and represent disabled people and to determine how society, in general, relates to them. The processes, regulations, and perceptions that guide the treatment of disabled persons in society create a history and a lived experience that binds individuals together as a culture of disabled people (Jaeger \& Bowman, 2005).

One of the oddly unifying elements of the disability experience is the general exclusion of disability from broader conversations about diversity. In many social contexts, such as education, disability is almost wholly removed from conversations about diversity; for example, disability is absent from diversity discussions, programs, and courses at most universities as well as from diversity training courses for the private sector (Davis, 2011). In one sense, this is highly ironic because disability is very diverse within itself and encompasses an enormous range of different conditions. Simply put, no type of diversity is more diverse than disability. Yet, in practice and application, disability is enormously isolated.

Many institutions view diversity as a value to embrace, promoting greater inclusion in terms of gender, race, ethnicity, orientation, and perhaps a few other characteristics. Disability, though, is often pushed aside and thought about as a matter of legal compliance. This distinction is most significant, as it means many institutions continue to functionally and effectively ignore disabled people, and the current political climate seems to be aggressively fostering disregard for disabled people.

\section{Enter Libraries}

In contrast to this awful treatment of disability, consider libraries. Many disabled individuals rely on libraries as a source of materials in accessible formats, as the only place in the community offering free Internet access and literacy education (with available assistive technologies), and as an institution that prioritized the rights of disabled people long before they came to be recognized by other parts and agencies of U.S. society. Libraries have long included disabled people as their community members. With their programs for facilitating the education, participation, empowerment, and inclusion of disabled people though information access and literacy, the activities of libraries fit firmly within the goals of the social model of disability.

The history of libraries serving people with disabilities is, in fact, long and distinguished, stretching back to the 1850s in the U.S. (Bertot \& Jaeger, 2015; Jaeger, Wentz, \& Bertot, 2015a; Wentz, Jaeger, \& Bertot, 2015). Libraries were often the first social or government institutions in many communities across the nation to resist the dehumanization of disabled people and to provide services that promoted their rights and equality in the community. The inclusion of disabled persons in libraries took place before people with disabilities gained basic rights in many other contexts, from the right to have an education or employment to the fundamental right to go outside and appear in public. Many U.S. cities in the 19th and 20th centuries had "ugly laws" that mandated that persons who were maimed, disfigured, or otherwise obviously disabled were not allowed in public view in community spaces, such as sidewalks, parks, and public buildings, including libraries in some places (Burgdorf \& Burgdorf, 1976; Siebers, 2003).

The International Journal of Information, Diversity, \& Inclusion, 2(1-2), 2018

ISSN 2574-3430, publish.lib.umd.edu/IJIDI/ 
The establishment of the first American Library Association (ALA) committee for services to people with disabilities in 1906 cemented the national leadership of libraries in the struggle for the inclusion of persons with disabilities. Soon after, following the guidance of the ALA, federal and state governments began to create special libraries of materials intended for people with disabilities, while libraries all over the nation started to build collections in new formats, such as records and talking books. In the social climate of the 1920s and 1930s, when eugenics laws in many states were promoting the mass sterilization of people with disabilities, libraries were formalizing and expanding their service to disabled patrons.

In 1961, the ALA crafted the first of a series of field-wide standards to ensure equal service to persons with disabilities. Within 20 years, public, school, and academic libraries had clear standards and mandates for services for individuals with disabilities, for accessible building designs, and for inclusive materials and services. The comprehensive "Library Services for People with Disabilities Policy" (ALA, 2001) is now more than 15 years old.

The practice of librarianship has continued to advance access for patrons with disabilities in light of changing needs and technologies. The adoption of the Internet in libraries led to more inclusive and accessible services for people with disabilities and became part of the discourse about library websites, online resources, digital libraries, and assistive technologies; by the same token, accessibility has asserted its place in broader discussions of inclusive library services (Jaeger, Wentz, \& Bertot, 2015b). A recent meta-analysis of all studies of web accessibility showed that the highest average levels of accessibility of websites are in libraries; the web presences of primary and secondary schools, colleges and universities, government agencies, nonprofits, and corporations are all significantly less accessible on average than those of libraries (Jaeger, 2012).

Today, libraries stand as the most inclusive community institution in U.S. society. While public libraries are the ones that may seem most connected to disabled people, it is found throughout the field. Law libraries, for example, not only find innovative ways to make legal materials accessible, but they are often leaders in promoting accessibility within law schools (Knight, 2017). As such, they serve as an example of a profession that is currently an ally and could become a significant partner in communication and advocacy. Librarianship has always been a politicized profession working to ensure inclusion; however, it has generally been quietly political (Jaeger \& Sarin, 2016a, 2016b). Given the very long engagement of libraries with promoting the rights and inclusion of disabled people, libraries seem like an ideal institution to partner with in the context of wider advocacy efforts. And the current political climate makes it imperative that people with disabilities have allies and advocates.

\section{“Nothing about Us Without Us"}

When what is now Section 504 of the Rehabilitation Act (29 U.S.C.A. 701 et seq.) was originally passed in 1973, it represented the first comprehensive set of legal rights and protections for disabled people in the U.S. (Fleischer \& Zames, 2001). The law represented a "transformation" of the status of disabled people in the U.S. by establishing "full social participation as a civil right" (Scotch, 2001, p. 3). Based on the Civil Rights Act of 1964 (42 U.S.C.A. 1971 et seq.), which guaranteed freedom from government discrimination based on race, color, and national origin, Section 504 of the Rehabilitation Act marked the first time disabled people were viewed under the law as full citizens in the U.S.-or at least it would have been if the law had been implemented. President Nixon signed the law and then promptly did nothing to enable its enactment and enforcement. Without the creation of regulations or guidelines for enforcement, the law was an empty statement, and even a successful lawsuit in federal courts did not sway the Nixon, Ford, or Carter administrations to implement it (Bowe, 1979; Fleischer \& Zames, 2001; Jaeger \& Bowman, 2002; Longmore, 2003). In fact, the Carter administration's response to the 
court order was to threaten to issue guidelines that would strip the law of all of its power (Shapiro, 1993).

Finally, a series of high-profile, creative, and coordinated protests in 1977 by a wide range of disability organizations and people with many different disabilities made the government act. Innovative actions, like wheelchair blockades of the home driveways of high-ranking officials in the Carter administration, and more traditional protests, like occupations of government buildings around the country, gained media and public attention. The protest that won the day, however, was the occupation of the Department of Health, Education, and Welfare office building in San Francisco, where 60 people with numerous types of physical, intellectual, and developmental disabilities held the building for 25 days. The federal government cut off food, water, and communication but did offer punch and cookies and other demeaning incentives to leave (Heumann, 1979). The protestors were supported by a network that included McDonald's, Safeway, the Black Panthers, various unions, and local and state politicians, who worked together to slip in food, water, information, and medical supplies to the protestors and bring out their messages (Barnartt \& Scotch, 2001; Longmore, 2003).

As the San Francisco occupation was a major national story, the U.S. Congress held a televised hearing on the Carter administration's opposition to the Rehabilitation Act. To respond to congressional inquiries, the administration sent a low-level official who explained that they planned to implement the law with changes such as exempting educational and health buildings from being accessible and excluding students with disabilities from general education (Longmore, 2003). The public filleting of this low-ranking official by members of Congress as well as a public airing of the absurdity of the administration's stance, presented against the backdrop of the San Francisco occupation, finally forced the Carter administration to implement the law in a way that did not dilute its impact.

Little more than a decade later, the ADA was being considered by Congress. The law was designed to extend the rights of people with disabilities into more settings, such as employment, shopping, travel, state and local government services, and universities. Many corporations, business advocacy groups, and conservative politicians lined up against the proposed law. However, once again, coordination was central to getting the law approved. Advocates focused less on gaining attention through the media coverage of protests and instead emphasized coordinated lobbying by disability advocacy groups (Shapiro, 1994). The few targeted protests highlighted specific kinds of discrimination in dramatic ways, like wheelchair users and others with mobility impairments crawling up the front stairs of buildings that lacked a ramp or other accessibility features (Fleischer \& Zames, 2001). As with the Rehabilitation Act protests, the key to success in getting the ADA passed and signed into law was collaboration between different advocacy groups and people with a range of disabilities.

The main message and rallying cry of these protests was "Nothing about us, without us." This slogan encapsulated the many ways in which prejudice toward disabled people is manifested and counteracted: on the one hand, the desire of the benevolent to make decisions for others and the ongoing paternalism that leads able-bodied people to profit-both literally and metaphorically-from disability and, on the other hand, the desire to be treated equitably and to have a political voice that makes disabled people central to decisions about disability policy. Yet, these successes were also facilitated by many allies who did not ignore disability or exclude it from the range of human diversity. With the changes now occurring in the nationalist, Trumpian political landscape, the help of allies and advocates, like libraries, will be most welcome in trying to change the narrative about and treatment of disabled people. 


\section{Libraries as Long-Term Allies of Disabled People}

As detailed above, libraries and the field of library and information science have traditionally viewed disabled people as members of the community and have focused on a form of diversity and inclusion that encompasses disability. A great range of programs, materials, and services intended for disabled people can be found at all types of libraries, with the oldest continuous programs reaching back to the mid-1800s. In truth, libraries have long been active supporters of disabled people and their inclusion in society. This history is central to the development of libraries, and it is a story that should be better known. Support from libraries predates the legal rights detailed above by more than a century.

In 1835, a lending service for materials for the blind was already available throughout New England, and the formalized creation of collections of materials in Braille began widely in 1868 (Charlson, 2000). Print materials for the blind also became part of many school library collections in the mid-1800s, and collections of materials in alternate formats were standard in larger public libraries by the early 1900s (Brown, 1971; Lovejoy, 1983). The Library of Congress's reading room for the blind opened in 1897 (Library of Congress, 1898). The American Library Association (ALA) founded a Committee for Library Work with the Blind in 1906 (Lovejoy, 1983). Talking books and talking book machines were commonly available to patrons with disabilities by the 1920s, with such books available first as records, then tapes, then discs, and now as digital files (Majeska, 1988; Neiland \& Thuronyi, 1994).

In this same time frame, the federal government and state governments began to create special libraries of materials specifically for people with disabilities. In 1904, U.S. postal regulations were altered so that "free matter for the blind or handicapped" could be shipped for free (St. John, 1957). The National Library Service (NLS) was established in 1931 and has relied on libraries as its backbone, with public libraries serving as regional and subregional libraries, distribution points, and referral services for the NLS (Dziedzic, 1983).

In 1961, the ALA crafted the first of a series of standards to ensure equal service for patrons with disabilities. Within 20 years, public libraries, school libraries, and academic libraries all had clear standards and mandates regarding accessible building design and inclusive materials and services for patrons with disabilities (Dziedzic, 1983; Gibson, 1977; Vasi, 1983; Vellman \& Miller, 1983).

Following the ALA's lead, the majority of public, academic, and school library mission statements articulate a commitment to equal access and services for all patrons, explicitly including people with disabilities. In most cases, these statements are now many decades old (Gibson, 1977). Most of these libraries have also been long committed to the acquisition of new assistive technologies as they become available-Braille materials, large-print materials, talking books, reading machines, video enlargement, screen readers, e-books, and screen magnifiers, among much else (McNulty, 2004). And the aforementioned early adoption and wide embrace of the Internet by libraries facilitated the availability of web-based services and technologies to disabled people, with libraries often being the only freely available access point for assistive technologies and accessible computing in many communities (Jaeger, 2012).

Now, inclusion of disabled people is usually an explicitly stated part of library missions, and, among ALA-accredited master's programs awarding Master of Library Science or Master of Library and Information Science degrees, knowledge of the legal rights of and the issues of service to patrons with disabilities is a required aspect of the curriculum (Walling, 2004). The ALA website features many recommendations, guidelines, and best practices for serving disabled patrons (www.ala.org/tools/guidelines/standardsguidelines), though much of the terminology could clearly use an update. The comprehensive accessibility of the program to disabled students is 
part of the ALA accreditation standards for Master of Library and Information Science programs (Council of the American Library Association, 2008). And while the preceding discussion has focused primarily on the U.S., the connection between libraries and the inclusion of people with disabilities has long and deep roots in many other nations as well (Lewis, 1983).

\section{Increasing Library Advocacy for Disabled People}

The history of interactions between libraries and disabled people emphatically demonstrates that libraries and librarianship have been and continue to be strong allies of disabled people, providing support, opportunities, and engagement that are often missing from other sectors of society. This commitment, of course, is not evenly applied across the field, and there are many opportunities to improve and strengthen this commitment to the inclusion of disabled people.

Thinking field-wide about ways to improve these connections between libraries and disabled people is extremely important in light of the increasing social and political hostility to disabled people. Few other societal institutions give much thought or effort to the inclusion of this group, and none have a lineage as venerable as libraries. Libraries are currently essential places of access and inclusion for disabled people.

The next step for libraries-in order to truly further the inclusion of disabled people-is to become advocates, arguing for changes both within libraries and in the broader community to improve the treatment of disabled people in society. Libraries have a legacy of contributions and commitment to social justice, and the inclusion of disabled people is an area in which there are many opportunities for promoting broader change. Some key possibilities within the library and its services include the following:

- ensure collections accurately represent disabled people,

- build collections to challenge prevailing social constructions about disability,

- incorporate issues of disability into more areas of outreach, partnership building, and community engagement to help create greater awareness of disability in the community, and

- foster new forums for making disability included more in the community.

All library activities related to disability can be enhanced by interviewing disabled people and incorporating those perspectives directly into development and refinement of such activities (Pionke, 2017; Pionke \& Manson, 2017). Helpfully, there is a growing number of resources available with ideas, strategies, and best practices for libraries, including multiple recently published or soon to-be-published books of essays on disability in libraries and the broader contexts of social justice (e.g., Copeland, in press; Epstein, in press; Gorham, Taylor, \& Jaeger, 2016; Wentz, Jaeger, \& Bertot, 2015).

Different kinds of libraries will also provide different avenues for influencing the inclusion of disabled people. The direct interactions between public libraries and their communities may seem to provide the most opportunities for impact, but each type of library can influence its own communities. As noted above, law libraries have taken a leadership role in promoting accessibility within law schools (Knight, 2017). In other kinds of special libraries, similar leadership is possible in other professional settings. Academic libraries have opportunities within the larger campus community to promote inclusive programming for community members with disabilities, emphasize disability issues in collection building and displays, and create research guides related to disability scholarship, among much else. 
This increased advocacy can also extend into Master of Library and Information Science (MLIS) education programs as well as other degree programs at information schools. Accessibility and disability issues are regularly taught in MLIS programs, but the greater contributions could come in teaching beyond the ALA requirements by offering advanced courses on accessibility and training information professionals to be ready to build born-accessible programs and services and advocate for equity for disabled people.

By making other community members more aware of the services and programs for disabled people, and the social and political barriers that make such services and programs necessary, libraries could actively educate other community members about disability. And by advancing the notion of disability as a core part of diversity, libraries could also be working to shift how others think about diversity.

A greater emphasis on advocacy could also move into the policy-making arena. While librarians have been generally reticent to engage in discussions of policy-making (Jaeger, Gorham, Bertot, \& Sarin, 2014; Jaeger \& Sarin, 2016a, 2016b), the area of disability is a space in which libraries have a great amount of expertise and historical commitment. The lessons from libraries could greatly inform thinking about disability in policy.

In a great many ways, libraries and library and information science (LIS) education are extremely well-positioned to become prominent allies of and advocates for disabled people. As some people in and outside the field wonder about the ongoing relevance of libraries, this topic points emphatically to why libraries and the field of LIS are more relevant than ever. We provide information, we promote inclusion and equity, and we foster rights.

\section{Acknowledgements}

The author is ineluctably grateful for the suggestions and keen insights of the reviewers in helping translate a scattered keynote talk into this paper.

\section{References}

Achenbach, J., \& Sun, H. L. (2017, May 23). Trump budget seeks huge cuts to science and medical research, disease prevention. Washington Post. Retrieved from https: / / www.washingtonpost.com/news/to-your-health/wp/2017/05/22/trumpbudget-seeks-huge-cuts-to-disease-prevention-and-medical-research-departments

Albrecht, G. L., Seelman, K. D., \& Bury, M. (Eds.). (2001). Handbook of disability studies. Thousand Oaks, CA: Sage.

American Library Association (2001). Library services for people with disabilities policy. Retrieved from http://www.ala.org/ascla/resources/libraryservices

Andre, L. (2003). Disability culture meets euthanasia culture: Lessons from my cat. Disability Studies Quarterly, 23(3/4). http://dx.doi.org/10.18061/dsq.v23i3/4.435

Bagenstos, S. R. (2009). Law and the contradictions of the disability rights movement. New Haven, CT: Yale University Press.

Balingit, M. (2017, October 21). DeVos rescinds 72 guidance documents outlining rights for disabled students. Washington Post. Retrieved from https: / / www.washingtonpost.com/news/education/wp/2017/10/21/devos-rescinds$\underline{72 \text {-guidance-documents-outlining-rights-for-disabled-students }}$ 
Barnartt, S., \& Scotch, R. (2001). Disability protests: Contentious politics 1970-1999. Washington, DC: Gallaudet University Press.

Bertot, J. C., \& Jaeger, P. T. (2015). The ADA and inclusion in libraries: Libraries have been and continue to be champions for access. American Libraries. Retrieved from http://americanlibrariesmagazine.org/blogs/the-scoop/ada-inclusion-in-libraries

Bowe, F. (1979). Handicapping America: Barriers to disabled people. In J. P. Hourihan (Ed.), Disability: Our challenge (pp. 87-106). New York: Teachers College, Columbia University.

Brault, M. W. (2012). Americans with disabilities: 2010. Report Number P70-131. Washington, DC: United States Census Bureau. Retrieved from https://www.census.gov/library/publications/2012/demo/p70-131.html

Brown, E. F. (1971). Library services to the disadvantaged. Metuchen, NJ: Scarecrow Press.

Bulmer, M. (2003). Francis Galton: Pioneer in heredity and biometry. Baltimore, MD: Johns Hopkins University Press.

Burgdorf, M., \& Burgdorf, R. L. (1976). History of unequal treatment: The qualifications of handicapped persons as a "suspect class" under the equal protection clause. Santa Clara Law Review, 15, 885-910.

Charlson, K. (2000). Braille library service. In F. K. Cykle (Ed.), Braille into the next millennium (pp. 236-255). Washington, DC: Library of Congress.

Copeland, C. (Ed.). (in press). See things differently: Libraries, disabilities, and abilities. Santa Barbara, CA: ABC-CLIO.

Cork, S. J., Jaeger, P. T., Jette, S., \& Ebrahimoff, S. (2016). The politics of (dis)information: Crippled America, the 25th anniversary of the Americans with Disabilities Act (ADA), and the 2016 United States presidential campaign. International Journal of Information, Diversity, and Inclusion. Retrieved from http://publish.lib.umd.edu/IJIDI/article/view/273

Council of the American Library Association. (2008). Standards for accreditation of master's programs in library \& information studies. Chicago: ALA.

Crouser, D. T. (2009). Signifying bodies: Disability in contemporary life writing. Ann Arbor: University of Michigan Press.

Davidson, J. (2017, April 21). Support grows for small agency with big reach on Trump's budget death row. Washington Post. Retrieved from https: / / www.washingtonpost.com/news/powerpost/wp/2017/04/21/support-forsmall-agency-with-big-reach-on-trumps-budget-death-row

Davis, L. (2011). Why is disability missing from the discourse on diversity? Chronicle of Higher Education. Retrieved from https://www.chronicle.com/article/Why-Is-DisabilityMissing-From/129088

Douglass, C., Gorham, U., Hill, R. F., Hoffman, K., Jaeger, P. T., Jindal, G., \& St. Jean, B. (2017). Information access and information literacy under siege: The potentially devastating impacts of the proposed 2017 White House budget on already-marginalized 
populations in the United States. First Monday, 22(10). Retrieved from http://firstmonday.org/ojs/index.php/fm/article/view/8088/6554

Dziedzic, C. (1983). Public libraries. In F. K. Cykle (Ed.), That all may read: Library service for blind and handicapped people (pp. 309-326). Washington, DC: Library of Congress.

Epstein, S. (Ed.). (in press). Tolerance: Social justice and activism in libraries, moving beyond diversity to action. Jefferson, NC: MacFarland.

Fleischer, D. Z., \& Zames, F. (2001). The disability rights movement: From charity to confrontation. Philadelphia: Temple University Press.

Friedlander, H. (1995). The origins of Nazi genocide: From euthanasia to the final solution. Chapel Hill: University of North Carolina.

Gibson, M. (1977). Preparing libraries to serve handicapped individuals. Journal of Education for Librarianship, 18, 123.

Gillham, N. W. (2001). A life of Sir Francis Galton: From African exploration to the birth of eugenics. Oxford, UK: Oxford University Press.

Gorham, U., Taylor, N. G., \& Jaeger, P. T. (Eds.). (2016). Perspectives on libraries as institutions of human rights and social justice. Bingley, UK: Emerald.

Heumann, J. E. (1979). Handicap and disability. In J. P. Hourihan (ed.), Disability: Our challenge (pp. 7-32). New York: Teachers College, Columbia University.

Hirschmann, N. J., \& Linker, B. (Eds.). (2015). Civil disabilities: Citizenship, membership, and belonging. Philadelphia: University of Pennsylvania Press.

Jaeger, P. T. (2012). Disability and the Internet: Confronting a digital divide. Boulder, CO: Lynne Rienner.

Jaeger, P. T. (2013). Internet justice: Reconceptualizing the legal rights of persons with disabilities to promote equal access in the age of rapid technological change. Review of Disability Studies, 9(1), 39-59.

Jaeger, P. T. (2015). Disability, human rights, and social justice: The ongoing struggle for online accessibility and equality. First Monday, 20(9). Retrieved from http://firstmonday.org/ojs/index.php/fm/article/view/6164/4898

Jaeger, P. T., \& Bowman, C. A. (2002). Disability matters: Legal and pedagogical issues of disability in education. Westport, CT: Bergin \& Garvey/Praeger.

Jaeger, P. T., \& Bowman, C. A. (2005). Understanding disability: Inclusion, access, diversity, \& civil rights. Westport, CT: Praeger.

Jaeger, P. T., Gorham, U., Bertot, J. C., \& Sarin, L. C. (2014). Public libraries, public policies, and political processes: Serving and transforming communities in times of economic and political constraint. Lanham, MD: Rowman \& Littlefield.

Jaeger, P. T., Gorham, U., Taylor, N. G., Sarin, L. C., \& Kettnich, K. (2017). Aftermath, part 2: Despite the way it may seem, all is not lost for libraries and librarianship. Library Quarterly, 87(4), 295-302. https://dx.doi.org/10.1086/693485 
Jaeger, P. T., \& Sarin, L. C. (2016a). All librarianship is political: Educate accordingly. Political Librarian, 2(1), 17-27. Available: http://openscholarship.wustl.edu/pollib/vol2/iss1/8

Jaeger, P. T., \& Sarin, L. C. (2016b). The politically engaged public library: Admitting and embracing the political nature of libraries and their goals. Public Library Quarterly, 35, 325-330.

Jaeger, P. T., Wentz, B., \& Bertot, J. C. (2015a). Libraries and the future of equal access for people with disabilities: Legal frameworks, human rights, and social justice. In B. Wentz, P. T. Jaeger, \& J. C. Bertot (Eds.), Accessibility for persons with disabilities and the inclusive future of libraries (pp. 237-253). Bingley, UK: Emerald.

Jaeger, P. T., Wentz, B., \& Bertot, J. C. (2015b). Accessibility, inclusion, and the roles of libraries. In B. Wentz, P. T. Jaeger, \& J. C. Bertot (Eds.), Accessibility for persons with disabilities and the inclusive future of libraries (pp. 1-8). Bingley, UK: Emerald.

Johnson, H. M. (2006). Too late to die young: Nearly true tall tales from a life. New York: Holt.

Knight, D. M. (2017). Providing disabled persons access to legal resources. AALL Spectrum, 22(2), 43-46.

Knittel, S. C. (2015). The historical uncanny: Disability, ethnicity, and the politics of Holocaust memory. New York: Fordham.

Lewis, M. J. (1983). In other countries. In F. K. Cykle (Ed.), That all may read: Library service for blind and handicapped people (pp. 381-410). Washington, DC: Library of Congress.

Library of Congress. (1898). Annual report of the librarian of Congress, 1897. Washington, DC: Government Printing Office.

Longmore, P. K. (2003). Why I burned my book and other essays on disability. Philadelphia: Temple University Press.

Longmore, P. K., \& Umansky, L. (Eds.). (2000). The new disability history: American perspectives. New York: New York University Press.

Lovejoy, E. (1983). History and standards. In F. K. Cykle (Ed.), That all may read: Library service for blind and handicapped people (pp. 1-24). Washington, DC: Library of Congress.

Majeska, M. L. (1988). Talking books: Pioneering and beyond. Washington, DC: Library of Congress.

McNulty, T. (2004). Libraries, media centers, online resources, and the research process. In C. A. Bowman \& P. T. Jaeger (Eds.), A guide to high school success for students with disabilities (pp. 117-131). Westport, CT: Greenwood.

Neiland, R. A., \& Thuronyi, G. F. (1994). Answering the call: Telephone pioneer talking-book machine-repair program. Washington, DC: Library of Congress.

Pfieffer, D. (1999). Eugenics and disability discrimination. In R. P. Marinelli \& A. E. Dell Orto (Eds.), The psychological and social impacts of disability (4th ed., pp. 12-31). New York: Springer. 
Pionke, J. J. (2017). Toward holistic accessibility: Narratives from functionally diverse patrons. Reference \& User Services Quarterly, 57, 48-56.

Pionke, J. J., \& Manson, J. (2017). Creating disability LibGuides with accessibility in mind. Journal of Web Librarianship, 12(1), 63-79. https://dx.doi.org/10.1080/19322909.2017.1396277

Prince, M. J. (2009). Absent citizens: Disability politics and policy in Canada. Toronto: University of Toronto Press.

Reilly, P. R. (1991). The surgical solution: A history of involuntary sterilization in the United States. Baltimore, MD: Johns Hopkins University Press.

St. John, F. R. (1957). Survey of library services for the blind, 1956. New York: American Foundation for the Blind.

Scheer, L., \& Gross, N. (1998). Impairment as human constant: Cross-cultural and historical perspectives on variation. Journal of Social Issues, 44, 23-37.

Schmetzke, A. (2002). Accessibility of web-based information resources for people with disabilities. Library Hi Tech, 20(2), 135-136.

Scotch, R. K. (2001). From goodwill to civil rights: Transforming federal disability policy (2nd ed.), Philadelphia: Temple University Press.

Scotch, R. K., \& Schriner, K. (1997). Disability as human variation: Implications for policy. Annals of the American Academy of Political and Social Science, 549, 148-159.

Siebers, T. (2003). What can disability studies learn from the culture wars? Cultural Critique, 55, 182-216.

Shapiro, J. P. (1993). No pity: People with disabilities forging a new civil rights movement. New York, NY: Times Books.

Shapiro, J. P. (1994). Disability policy and the media: A stealth civil rights movement bypasses the press and defies conventional wisdom. Policy Studies Journal, 22, 123-132.

Shigaki, C. L., Anderson, K. M., Howald, C. L., Henson, L., \& Gregg, B. E. (2012). Disability on campus: A perspective from faculty and staff. Work, 42(4), 559-571.

Smart, J. (2001). Disability, society and the individual. Gaithersburg, MD: Aspen Publications.

Snell, K., Paletta, D., \& DeBonis, M. (2017, May 23). Even some Republicans balk at Trump's plan for steep budget cuts. Washington Post. Retrieved from https: / / www.washingtonpost.com/powerpost/even-some-republicans-balk-at-trumpsplan-for-steep-budget-cuts/2017/05/23/9bf202f8-3f62-11e7-adba394ee67a7582_story.html

Stiker, H. J. (1999). A history of disability (W. Sayers, Trans.). Ann Arbor: University of Michigan Press.

Strauss, V. (2017a, January 3). Betsy DeVos apparently "confused" about federal law protecting students with disabilities. Washington Post. Retrieved from 
https: / / www.washingtonpost.com/news/answer-sheet/wp/2017/01/17/betsy-devosconfused-about-federal-law-protecting-students-with-disabilities

Strauss, V. (2017b, April 7). Why the word "merely" turned many advocates for students with disabilities against Gorsuch. Washington Post. Retrieved from https: / / www.washingtonpost.com/news/answer-sheet/wp/2017/04/07/why-the-wordmerely-turned-many-advocates-for-students-with-disabilities-against-gorsuch

Strauss, V. (2017c, January 28). The telling letter Betsy DeVos wrote to clarify her position on U.S. disabilities law. Washington Post. Retrieved from https: / /www.washingtonpost.com/news/answer-sheet/wp/2017/01/28/the-tellingletter-betsy-devos-wrote-to-clarify-her-position-on-u-s-disabilities-law

Stroman, D. F. (2003). The disability rights movement: From deinstitutionalization to selfdetermination. Lanham, MD: Rowman \& Littlefield.

Trump, D. J. (2015). Crippled America: How to make America great again. New York: Threshold Editions.

Vasi, J. (1983). Academic library services. In F. K. Cykle (Ed.), That all may read: Library service for blind and handicapped people (pp. 327-346). Washington, DC: Library of Congress.

Vellman, R. A., \& Miller, J. A. (1983). School library media services. In F. K. Cykle (Ed.), That all may read: Library service for blind and handicapped people (pp. 287-308). Washington, DC: Library of Congress.

Walling, L. L. (2004). Educating students to serve information seekers with disabilities. Journal of Education for Library and Information Science, 45, 137-148.

Wentz, B., Jaeger, P. T., \& Bertot., J. C. (Eds.). (2015). Accessibility for persons with disabilities and the inclusive future of libraries. Bingley, UK: Emerald.

Willingham, E. (2016, July 27). This is what disability erasure looks like. Forbes. Retrieved from http://www.forbes.com/sites/emilywillingham/2016/07/27/killer-of-disabled-peoplein-japan-announced-his-intentions-months-ago/\#1954b64c2942

World Bank. (2017). Disability inclusion overview. Retrieved from www.worldbank.org/en/topic/disability

Zaikowski, C. (2017, February 3). Canada is a progressive immigration dream-unless you have a disability. Washington Post. Retrieved from https: / / www.washingtonpost.com/posteverything/wp/2017/02/03/canada-is-aprogressive-immigration-policy-dream-unless-you-have-a-disability

Paul T. Jaeger, Ph.D., J.D., is Professor, Diversity \& Inclusion Officer, and Director of the Master of Library and Information Science (MLIS) program of the College of Information Studies and CoDirector of the Information Policy and Access Center (iPAC) at the University of Maryland. He is the author of more than 170 journal articles and book chapters, as well as more than a dozen books. His research has been funded by the Institute of Museum \& Library Services, the National Science Foundation, and the Bill \& Melinda Gates Foundation, among others. Dr. Jaeger is Editor of Library Quarterly, Editor of Advances in Librarianship, and Associate Editor of the International Journal of Information, Diversity, \& Inclusion. He is founder of the Conference on Inclusion and 
Diversity in Library and Information Science (CIDLIS), and co-founder of the UMD Disability Summit. In 2014, he received the Library Journal/ALISE Excellence in Teaching Award. 